University for Business and Technology in Kosovo

UBT Knowledge Center

Oct 27th, 9:00 AM - 10:30 AM

\title{
Study of Foods Declared as GMO Free in the Market of Republic of Kosovo
}

\author{
Ismail Ferati \\ University for Business and Technology, ismajl.ferati@ubt-uni.net \\ Namik Durmishi \\ University for Business and Technology \\ Diellëz Arifı \\ University for Business and Technology \\ Sara Selim \\ University for Business and Technology \\ Ardit Hoti \\ University for Business and Technology
}

Follow this and additional works at: https://knowledgecenter.ubt-uni.net/conference

Part of the Food Science Commons

\section{Recommended Citation}

Ferati, Ismail; Durmishi, Namik; Arifi, Diellëz; Selim, Sara; and Hoti, Ardit, "Study of Foods Declared as GMO Free in the Market of Republic of Kosovo" (2018). UBT International Conference. 190.

https://knowledgecenter.ubt-uni.net/conference/2018/all-events/190

This Event is brought to you for free and open access by the Publication and Journals at UBT Knowledge Center. It has been accepted for inclusion in UBT International Conference by an authorized administrator of UBT Knowledge Center. For more information, please contact knowledge.center@ubt-uni.net. 


\title{
Study of Foods Declared as GMO Free in the Market of the Republic of Kosovo
}

\author{
Ismail Ferati $^{1}$, Namik Durmishi ${ }^{1}$, Diellëz Arifi ${ }^{1}, \operatorname{Sara~Selim}^{1}, \operatorname{Ardit~Hoti~}^{1}$ \\ UBT Higher Education Institution, Lagjja Kalabria p.n., Prishtinë, Kosovë \\ ismajl.ferati@ubt-uni.net
}

\begin{abstract}
In this study, several samples from two different producers that are present in the Kosovo market and which are declared as GMO free are analyzed, the method of analysis is Agrastrip ${ }^{\circledR}$ GMO - Romer labs ${ }^{\circledR}$. Samples were taken on a random basis in the market and the focus of the study were two products (corn and soy). As this problem is relatively new in the Republic of Kosovo, some theoretical and practical issues will be addressed by referring to the researchers in this field: what are GMOs and why GM foods are produced, the distinction to be made (myths and facts, socio-economic aspects), side effects (environment and health), bees as being of being dependent on existence and life (especially in food, relationship with GMOs).
\end{abstract}

Keywords: GMOs, GMO FREE, Agrastrip ${ }^{\circledR}$ GMOs - Romer labs®, corn, soy

\section{Introduction}

In this project, we have treated a very controversial topic which is GMOs. The subject is very wide but we tried treating the problems from the basic concerns which are correlated with the topic. From showing what they are, why are they used for and what are the effects of them in our health and environment, to a study with several samples which were analysed in lab. Also in this study several samples from two different producers that are present in the Kosovo market and which are declared as GMO free are analyzed, the method of analysis is Agrastrip ${ }^{\circledR}$ GMO Romer labs ${ }^{\circledR}$. Samples were taken on a random basis in the market and the focus of the study were two products (corn and soy). As this problem is relatively new in the Republic of Kosovo, some theoretical and practical issues will be addressed by referring to the researchers in this field: what are GMOs and why GM foods are produced, the distinction to be made (myths and facts, socio-economic aspects), side effects (environment and health), bees as being of being dependent on existence and life (especially in food, relationship with GMOs). 


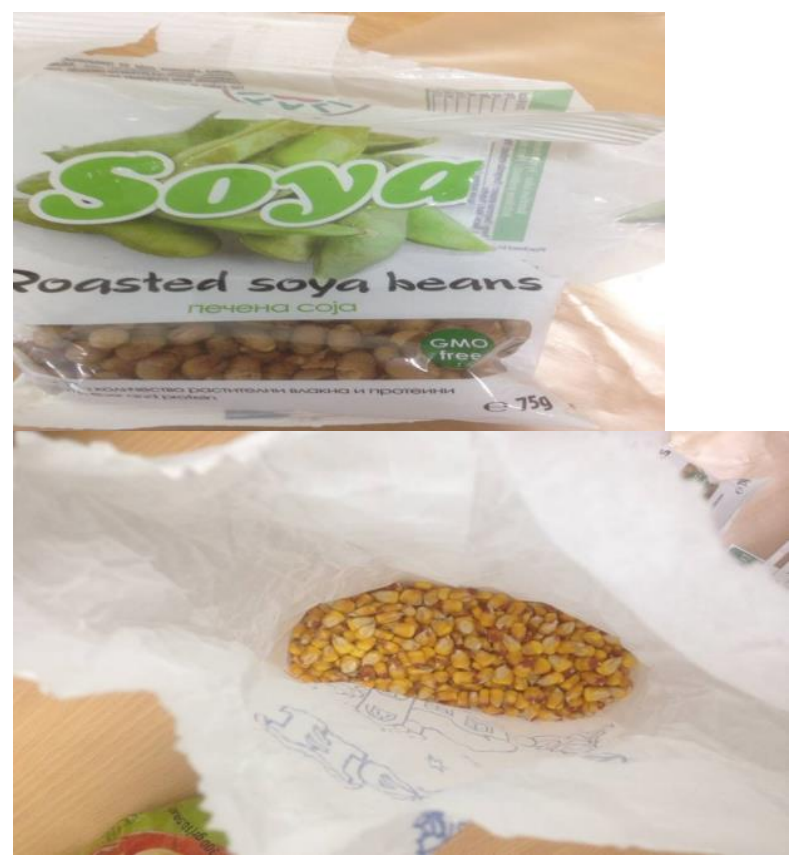

\title{
Materials and methods
}

\author{
Experiment Required tools: \\ Glass jars \\ Blender
}

Corn bean

Soy bean

GMO kits

The way we concluded the results: The samples were taken on a random basis in the market. It should also be noted that the samples were analyzed in the laboratories of the Faculty of Food Science and Biotechnology - UBT. During this experiment we analyzed two products (soy and corn), the purpose of this experiment was to confirm if these products marked as free GMO are true.This method consists on The AgraStrip ${ }^{\circledR}$ test kits are ready-to-use lateral flow devices (LFD) for on-site testing. These allow a rapid analysis of a wide range of commodities within only 6 minutes First, an amount of corn and soybean grains were crushed by blender and the sample was homogenized. Then $10 \mathrm{~g}$ of each sample was taken and placed in laboratory glassware with $500 \mathrm{ml}$ volume and filled with distilled water up to $200 \mathrm{ml}$. After the samples are placed, the product is homogenized. Then the agrotrip GMO test kits are placed in the samples and left in a position for 15 minutes. After 5 minutes, the kit is removed and the results were shown in a visual way.

A single violet line at the center of the test - negative test

Two lines at the center of the test - positive test

No lines at the center of the test - invalid test 


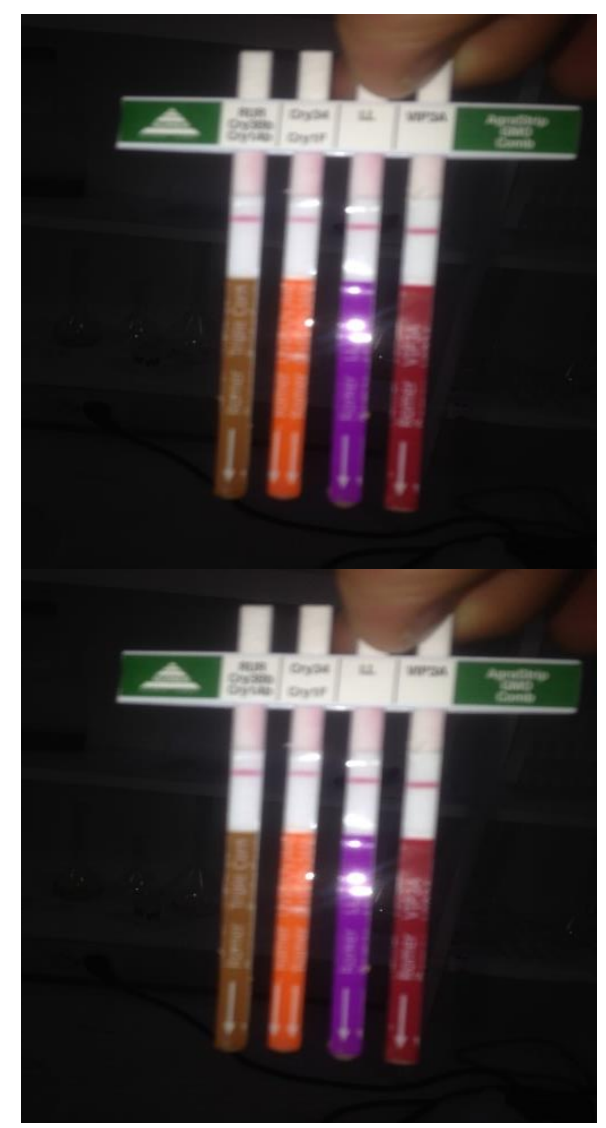

AgraStrip ${ }^{\circledR}$ Test

\section{Results and discussion}

The results obtained during this study show that the results were negative, thus analyzed samples were not genetically modified. Which indicates that the products obtained in the study and which are declared as GMO free, have not resulted genetic modifications. This study is from random studies conducted in the republic of Kosovo, therefore we hope to be an incentive for wider testimonies in our country. 


\section{Conclusions}

Based on the results of this study we can conclude that:

1. The products analyzed meet their objectives to have GMO free products on the market;

2. None of the analyzed soy samples did not prove positive in the AgraStrip® test;

3. None of the analyzed corn samples did not prove positive in the AgraStrip ${ }^{\circledR}$ test;

4. Most of the food in the Republic of Kosovo are not declared as GMO free;

5. We recommend competent institutions to deal with this issue in cooperation with scientific institutions, to have a realistic understanding of what foods are consuming the population in the Republic of Kosovo;

\section{References}

1. https://shop.romerlabs.com/en/AgraStrip-LFD/AgraStrip-GMO

2. Nash N. Germany shuns biotechnology [Internet]. New York (NY): New York Times: c1994 21 Sep [cited 2013 Mar 25]. Available from

http://www.nytimes.com/1994/12/21/business/germany-shuns-biotechnology.html [Google Scholar].

3. Balaj I, Nedelea G, Badea EM. Effects of applying EU legislation on cultivation of transgenic herbicide-resistant soybean in Romania. . Journal of Horticulture, Forestry and Biotechnology 2012; 16:52 - 6 [Google Scholar].

4. United States Food and Drug Administration (FDA), "Questions \& Answers on Food from Genetically Engineered Plants,"

5. http://www.fda.gov/ food/foodscienceresearch/biotechnology/ucm346030.htm, last updated Apr. 7, 2013.

6. WHO, "20 questions on genetically modified foods," http://www.who.int/ foodsafety / publications / biotech / 20questions / en / index.html, accessed on Nov 21, 2013.

7. Food Safety Department, "World Health Organization, Modern Food Biotechnology, Human Health and Development: an Evidence Based Study,"

8. http://www.who.int/foodsafety/publications/biotech/biotech_en.pdf.

9. https://eur-lex.europa.eu/legal-content/EN/ALL/?uri=CELEX:32003R1829

10. https://eur-lex.europa.eu/legal-content/EN/TXT/?uri=CELEX:32015L0412 